\title{
Ocean acidification and desalination: climate-driven change in a Baltic Sea summer microplanktonic community
}

\author{
Angela Wulff ${ }^{1}\left[\right.$ (]) Maria Karlberg ${ }^{1} \cdot$ Malin Olofsson $^{2} \cdot$ Anders Torstensson $^{1,5} \cdot$ Lasse Riemann $^{3}$. \\ Franciska S. Steinhoff ${ }^{1} \cdot$ Malin Mohlin $^{4} \cdot$ Nina Ekstrand ${ }^{2} \cdot$ Melissa Chierici $^{2,6}$
}

Received: 13 February 2017 / Accepted: 1 March 2018 / Published online: 9 March 2018

(c) The Author(s) 2018. This article is an open access publication

\begin{abstract}
Helcom scenario modelling suggests that the Baltic Sea, one of the largest brackish-water bodies in the world, could expect increased precipitation (decreased salinity) and increased concentration of atmospheric $\mathrm{CO}_{2}$ over the next 100 years. These changes are expected to affect the microplanktonic food web, and thereby nutrient and carbon cycling, in a complex and possibly synergistic manner. In the Baltic Proper, the extensive summer blooms dominated by the filamentous cyanobacteria Aphanizomenon sp., Dolichospermum spp. and the toxic Nodularia spumigena contribute up to $30 \%$ of the yearly new nitrogen and carbon exported to the sediment. In a 12 days outdoor microcosm experiment, we tested the combined effects of decreased salinity (from 6 to 3 ) and elevated $\mathrm{CO}_{2}$ concentrations (380 and $960 \mu \mathrm{atm}$ ) on a natural summer microplanktonic community, focusing on diazotrophic filamentous cyanobacteria. Elevated $p \mathrm{CO}_{2}$ had no significant effects on the natural microplanktonic community except for higher biovolume of Dolichospermum spp. and lower biomass of heterotrophic bacteria. At the end of the experimental period, heterotrophic bacterial abundance was correlated to the biovolume of $N$. spumigena. Lower salinity significantly affected cyanobacteria together with biovolumes of dinoflagellates, diatoms, ciliates and heterotrophic bacteria, with higher biovolume of Dolichospermum spp. and lower biovolume of $N$. spumigena, dinoflagellates, diatoms, ciliates and heterotrophic bacteria in reduced salinity. Although the salinity effects on diatoms were apparent, they could not clearly be separated from the influence of inorganic nutrients. We found a clear diurnal cycle in photosynthetic activity and $\mathrm{pH}$, but without significant treatment effects. The same diurnal pattern was also observed in situ $\left(p \mathrm{CO}_{2}, \mathrm{pH}\right)$. Thus, considering the Baltic Proper, we do not expect any dramatic effects of increased $p \mathrm{CO}_{2}$ in combination with decreased salinity on the microplanktonic food web. However, long-term effects of the experimental treatments need to be further studied, and indirect effects of the lower salinity treatments could not be ruled out. Our study adds one piece to the complicated puzzle to reveal the combined effects of increased $p \mathrm{CO}_{2}$ and reduced salinity levels on the Baltic microplanktonic community.
\end{abstract}

\section{Introduction}

The Baltic Sea, one of the largest brackish-water bodies in the world, represents an ecosystem highly influenced by eutrophication, mediated especially by anthropogenic nutrient loading (Gustafsson et al. 2012; Kahru and Elmgren 2014). The central Baltic Sea has been proposed to be subject for a discontinuous regime shift due to climate change in

Responsible Editor: N. Aberle-Malzahn.

Reviewed by Undisclosed experts.

Angela Wulff

angela.wulff@bioenv.gu.se

Extended author information available on the last page of the article combination with anthropogenic pressure (Möllmann et al. 2009). Expected effects of climate change may compromise the Baltic Sea as a recreational and economical resource and there are strong indications that an increased frequency or duration of cyanobacteria summer blooms will cause serious harm to, e.g. tourism industries (Hasselström 2008), and additional impact on ecosystem health, e.g. oxygen depletion (Kabel et al. 2012).

Over the next 100 years, the Baltic Sea is expected to undergo a temperature increase by $2-5{ }^{\circ} \mathrm{C}$ and experience increased precipitation rates, presumably leading to decreased salinity (HELCOM 2013). Concomitantly, the concentration of atmospheric $\mathrm{CO}_{2}$ will increase from current values of ca. $390 \mu$ atm up to $>970 \mu$ atm by year 2100 (Meehl et al. 2007; IPCC 2013). These changes will likely 
affect all trophic levels of the planktonic food web. Thereby, nutrient and carbon cycling will be affected in a complex and possibly synergistic manner. Due to the complexity of the systemic response, bi- and multifactorial approaches rather than single-factor experiments (Havenhand 2012; Lindh et al. 2013; Karlberg and Wulff 2013; Eichner et al. 2014a; Riebesell and Gattuso 2015) are required to decipher linkages between particular environmental changes and responses at various trophic levels of the food web.

In the Baltic Proper, the extensive summer blooms of cyanobacteria contribute up to $30 \%$ of the yearly new nitrogen and carbon exported to the sediment (HELCOM 2007), and the blooms are dominated by the filamentous taxa Aphanizomenon sp., Dolichospermum spp. (formerly Anabaena spp.) and the toxic Nodularia spumigena. Cyanobacterial nitrogen is assimilated and transferred in Baltic food webs directly through grazing, or indirectly through bioavailable nitrogen exuded from cyanobacterial cells (Ploug et al. 2010, 2011; Karlson et al. 2015). Due to group-specific differences in carbon uptake and saturation states of photosynthetic rates, increased $\mathrm{CO}_{2}$ concentrations will affect photosynthesis (Raven et al. 2005; Reinfelder 2011) as well as phytoplankton community composition (Bermúdez et al. 2016). In laboratory experiments using filamentous Baltic cyanobacteria, here N. spumigena, the effects of elevated $\mathrm{CO}_{2}$ levels on growth ranged from decreased growth (Eichner et al. 2014b) to increased growth rate (Wannicke et al. 2012). However, lack of effects has also been reported for N. spumigena, Aphanizomenon sp. (Karlberg and Wulff 2013) and Dolichospermum spp. (Brutemark et al. 2015). For heterotrophic bacteria, theoretically, increased $\mathrm{CO}_{2}$ levels should probably not show any direct effects (Joint et al. 2011), but direct effects with higher bacterial abundance at elevated $p \mathrm{CO}_{2}$ have nevertheless been shown (Endres et al. 2014). Increased phytoplankton biomass or productivity mediated by elevated $p \mathrm{CO}_{2}$ may stimulate growth of particle-associated bacteria (Grossart et al. 2006; Engel et al. 2013). Hence, consequences of elevated $p \mathrm{CO}_{2}$ levels for bacterioplankton are indeed difficult to predict.

Although the Baltic diazotrophic filamentous cyanobacteria seem to tolerate a wide salinity range, some differences between species have been reported. Compared to Aphanizomenon sp. (Lehtimäki et al. 1997; Laamanen et al. 2002), the toxic $N$. spumigena seems to tolerate a wider salinity range (5-30) with a biomass peak at salinity 10 (Lehtimäki et al. 1997) or 7 (Mazur-Marzec et al. 2005) Anabaena spp. (now Dolichospermum spp.) seems to prefer lower salinities and showed both higher growth rates and toxin concentrations at salinity 1-2 relative to salinity 5-6 (Engström-Öst et al. 2011). For heterotrophic bacteria, surface waters of the central Baltic Sea harbour members of typical freshwater bacterial groups and lack several typical marine taxa (Riemann et al. 2008; Herlemann et al. 2011). Hence, the estuarine/brackish local conditions have shaped a bacterioplankton community uniquely adapted to the local salinity regime.

The aim of this study was to test impacts of the A1FI scenario (Meehl et al. 2007) on a natural Baltic microbial community, focusing on the three dominating filamentous cyanobacteria species during the summer bloom. This scenario projects increased atmospheric $\mathrm{CO}_{2}$ levels (from 380 to $960 \mu \mathrm{atm}$ ), and decreased salinity (by 3 units, here from 6 to 3 ) for the Baltic Proper in 2100. To shed some light into the complexity of the microbial ecosystem response, we studied interactive effects of $p \mathrm{CO}_{2}$ and salinity in an outdoor experimental setup with ambient radiation and temperature conditions.

\section{Materials and methods}

\section{Experimental setup}

The experiment was conducted between 16 and 28 July 2010 outside of Askö Laboratory $\left(58^{\circ} 49^{\prime} \mathrm{N}, 17^{\circ} 38^{\prime} \mathrm{E}\right)$ in the Baltic Sea. A natural community of Baltic Sea pelagic microplankton, dominated by the cyanobacterium Aphanizomenon sp. was collected using plankton net (mesh size $25 \mu \mathrm{m}$ ). To avoid large grazers, the collected organisms were gently filtered through a $200 \mu \mathrm{m}$ mesh. The microbes, including organisms $<25 \mu \mathrm{m}$ associated/attached to the phytoplankton, were inoculated in $0.2 \mu \mathrm{m}$ filtered Baltic Sea surface water with either salinity 6 (ambient) or 3 (reduced), and divided into $4 \mathrm{~L}$ ultraviolet (UV) transparent Plexiglas aquaria (Mohlin and Wulff 2009). Reduced salinity was obtained by diluting natural Baltic Sea water with Milli-Q water and by compensating inorganic nutrient dilution by the addition of nutrients following N:P ratios of $f / 2$ medium (Guillard 1975). The resulting nutrient concentrations on Day 0 are shown in Table 2 . The aquaria were randomly placed in four basins filled with continuous flow-through seawater, exposing the microbes to natural fluctuations of temperature. Temperature in each basin was recorded with a logger (HOBO Pendant, Onset Computer Corporation, Bourne, USA). The basins were covered with green plastic mesh to reduce the irradiance, resulting in an approximate $60 \%$ reduction of the photosynthetically active radiation (PAR, 400-700 nm). This reduction was equivalent to PAR intensities at water depths of $1-2 \mathrm{~m}$ in the surrounding water column at the sampling site, as measured with an LI-1000 datalogger equipped with a Li-COR UWQ5201 PAR sensor (Li-COR, Lincoln, USA). A PMA2100 radiometer equipped with a $2 \pi$ PMA2132 PAR sensor and a PMA2110 UV-A sensor (Solar Light, Glenside, USA) was used to record irradiances under the mesh throughout the experiment. 
For each of the two salinity treatments, two partial pressures of $\mathrm{CO}_{2}\left(p \mathrm{CO}_{2}\right)$ were established by connecting each aquarium with a tube, constantly providing synthetic air (AGA Gas, Linköping, Sweden) with a $p \mathrm{CO}_{2}$ of either 380 $\mu$ atm (ambient $p \mathrm{CO}_{2}$ ) or $960 \mu$ atm (enriched $p \mathrm{CO}_{2}$ ). The treatments are denoted as $\mathrm{S} 6 \mathrm{Amb}$ (salinity 6 and $p \mathrm{CO}_{2} 380$ $\mu$ atm), S6 High (salinity 6 and $p \mathrm{CO}_{2} 960 \mu \mathrm{atm}$ ) S3 Amb (salinity 3 and $p \mathrm{CO}_{2} 380 \mu \mathrm{atm}$ ) and S3 High (salinity 3 and $\left.p \mathrm{CO}_{2} 960 \mu \mathrm{atm}\right)$. The gas was dispersed to the water by ceramic air diffusers at a flow rate of $\sim 15 \mathrm{ml} \mathrm{min}^{-1}$. For the $p \mathrm{CO}_{2} 960 \mu \mathrm{atm}$ treatment, the effect of flow velocity (3, 9 and $15 \mathrm{ml} \mathrm{min}^{-1}$ ) was tested in triplicate experimental aquaria over 4 days using a culture of $N$. spumigena with a cell density corresponding to total phytoplankton cell density at Day 0 . Target $p \mathrm{CO}_{2}$ was reached at $9 \mathrm{ml} \mathrm{min}^{-1}$ but $15 \mathrm{ml} \mathrm{min}{ }^{-1}$ was chosen to compensate for an increased cell density over time. The aquaria were sealed with Plexiglas lids using silicon glue for aquaria, and small holes were maintained for gas outlet to prevent backpressure buildup. In addition, each aquarium was provided with a submerged tube connected to an external syringe, which was used to remove subsamples from the aquaria without opening the lids and, thus, disturb the $p \mathrm{CO}_{2}$ of the headspace. Quadruplicated aquaria from each of the four treatments were subsampled around 08.00 a.m. at five occasions (Days 0, 3, 5, 9 and 12) during the experiment. In addition, between Days 10 and 11, subsamples were analysed hourly for $30 \mathrm{~h}$ to study the diurnal cycle of $\mathrm{pH}$ and photosynthetic efficiency (Pulse Amplitude Modulated fluorometer, Walz Mess- und Regeltechnik, Effeltrich, Germany). After sampling, at Days 2, 5 and $9,7 \mathrm{ml}$ of $f / 2$ medium without nitrate and silicate was added to every litre of the remaining sample (aiming at $0.3 \mu \mathrm{M}$ DIP) to maintain concentrations similar to the Baltic Sea's summer nutrient conditions. In an additional set of four aquaria manipulated with ambient levels, i.e. salinity 6 and $380 \mu \mathrm{atm} \mathrm{CO}_{2}$, no nutrients were added and used as a control for nutrient enrichment. To observe whether there were biological or chemical processes changing the carbonate system, one additional aquarium per treatment was set up without any microbes as a control. Because the aim of the experiment was to investigate potential combined effects of salinity and $p \mathrm{CO}_{2}$, samples from "nutrient controls" are not included in statistical analyses, but results from inorganic and particulate organic nutrient analyses, carbon chemistry and chlorophyll a $(\operatorname{chl} a)$ are shown in Tables $1,2,3$. A field measurement of diurnal changes in $\mathrm{pH}$ and $p \mathrm{CO}_{2}$ was performed between Days 4 and 5; samples were taken every second hour over $24 \mathrm{~h}$.

\section{Phytoplankton species composition and growth}

At Days 0, 3, 5, 9 and 12, $50 \mathrm{ml}$ from each aquarium was preserved with alkaline Lugol's solution, stored in the dark and analysed within 3 months using the Utermöhl method according to HELCOM (2008). Half of the bottom surface of the chamber was viewed in $10 \times$ magnification (Axiovert 40CFL, Micrometer Ocular 444232 E-Pl 10×/20, Zeiss, Oberkochen, Germany) and all organisms larger than $30 \mu \mathrm{m}$ was counted and grouped, either to species level or order. The length and width of filamentous species were also measured and the biovolume $\left(\mathrm{mm}^{3} \mathrm{l}^{-1}\right)$ was calculated. In both $20 \times$ and $40 \times$ magnification, a diagonal of the chamber bottom was analysed and organisms including micrograzers (e.g. ciliates) no smaller than $8 \mu \mathrm{m}$ were counted.

The growth rate $\left(\mathrm{mm}^{3} \mathrm{day}^{-1}\right)$ for each cyanobacteria species was calculated separately for Days 0 to 3 and Days 9 to 12 . The specific growth rate $\left(\mu \mathrm{day}^{-1}\right)$ was calculated according to $(\ln D \mathrm{~B}-\ln D \mathrm{~A}) /(t \mathrm{~B}-t \mathrm{~A})$, where $D \mathrm{~A}$ is the
Table 1 Concentrations of photosynthetic pigments and biovolume of micrograzers

\begin{tabular}{lllllllll}
\hline Day & Treatment & Chl $a$ & Fucox & Myxo & Canthax & Echin & Rotifers & Ciliates \\
\hline 0 & S6 Amb & na & na & na & na & na & $2.36(0.30)$ & $0.02(0.01)$ \\
& S3 Amb & na & na & na & na & na & $2.46(0.43)$ & $0.06(0.03)$ \\
& S6 High & na & na & na & na & na & $1.52(0.11)$ & $0.06(0.04)$ \\
& S3 High & na & na & na & na & na & $1.82(0.27)$ & $0.03(0.01)$ \\
Control & & & & & & & \\
12 & S6 Amb & $3.36(1.47)$ & $0.13(0.05)$ & $0.28(0.13)$ & $0.16(0.06)$ & $0.18(0.08)$ & $3.00(0.48)$ & $0.29(0.07)$ \\
& S3 Amb & $5.68(1.5)$ & $0.22(0.15)$ & $0.88(0.15)$ & $0.23(0.06)$ & $0.43(0.11)$ & $2.25(0.17)$ & $0.25(0.06)$ \\
& S6 High & $2.55(0.25)$ & $0.07(0.02)$ & $0.44(0.23)$ & $0.11(0.01)$ & $0.13(0.04)$ & $2.97(0.33)$ & $0.56(0.09)$ \\
& S3 High & $8.71(2.04)$ & $0.10(0.02)$ & $1.03(0.30)$ & $0.33(0.03)$ & $0.64(0.10)$ & $2.59(0.71)$ & $0.24(0.09)$ \\
Control & $1.06(0.11)$ & & & & & & \\
\hline
\end{tabular}

Pigment data are expressed as $\mu \mathrm{g}$ pigments $\mathrm{l}^{-1}$ for chlorophyll $a(\mathrm{Chl} a$ ), fuxocanthin (Fucox), myxoxanthophyll (Myxo), canthaxanthin (Canthax), and echinenone (Echin). The biovolumes of two micrograzer groups (rotifers and ciliates) are expressed in $\mathrm{mm}^{3} \mathrm{l}^{-1}$. The different treatments are four combinations of salinity (S6, S3) and carbon dioxide concentrations (Amb, High). Controls denote an extra treatment (S6 $\mathrm{Amb}$ ) without nutrient enrichment. Numbers show mean values of four replicate treatments and standard error is shown between brackets 
Table 2 Concentrations of inorganic nitrogen (DIN, $\mathrm{NO}_{2}{ }^{-}$and $\mathrm{NO}_{3}{ }^{-}$), phosphate (DIP, $\mathrm{PO}_{4}{ }^{3-}$ ), silicic acid ( $\mathrm{Si}$ ), particulate organic carbon (POC), nitrogen (PON) and phosphorus (POP)

\begin{tabular}{lllllllllll}
\hline Day & Treatment & DIN & DIP & Si & DIN:DIP & POC & PON & POP & POC:PON & POC:PON:POP \\
\hline 0 & S6 Amb & $5.37(0.22)$ & $0.31(0.02)$ & $10.31(0.28)$ & $17.5(1.19)$ & $214(17)$ & $22.67(2.18)$ & $0.88(0.03)$ & $9.53(0.63)$ & $244: 26: 01$ \\
& S3 Amb & $3.05(0.37)$ & $0.27(0.01)$ & $5.33(1.01)$ & $11.5(0.96)$ & $114(31)$ & $12.28(3.23)$ & $0.86(0.02)$ & $9.16(0.18)$ & $134: 14: 01$ \\
& S6 High & $5.34(0.06)$ & $0.46(0.03)$ & $10.50(0.54)$ & $11.3(0.60)$ & $287(59)$ & $31.42(5.58)$ & $0.91(0.02)$ & $9.02(0.47)$ & $317: 35: 01$ \\
& S3 High & $3.06(0.18)$ & $0.26(0.01)$ & $5.84(0.24)$ & $12.1(0.58)$ & $112(14)$ & $12.41(1.49)$ & $0.86(0.02)$ & $9.02(0.38)$ & $132: 15: 01$ \\
& Control & $5.43(0.51)$ & $0.29(0.02)$ & $11.52(0.98)$ & $19.5(1.34)$ & $176(29)$ & $21.03(3.54)$ & $0.88(0.01)$ & $8.39(0.08)$ & $199: 24: 01$ \\
12 & S6 Amb & $0.20(0.04)$ & $0.08(0.03)$ & $0.61(0.09)$ & $2.75(1.80)$ & $106(22)$ & $11.64(2.59)$ & $1.45(0.07)$ & $9.20(0.20)$ & $74: 08: 01$ \\
& S3 Amb & $0.21(0.04)$ & $0.11(0.02)$ & $0.63(0.17)$ & $1.67(0.52)$ & $46(13)$ & $4.66(1.34)$ & $1.24(0.08)$ & $9.53(0.23)$ & $38: 04: 01$ \\
& S6 High & $0.18(0.03)$ & $0.23(0.04)$ & $0.77(0.29)$ & $0.75(0.16)$ & $151(19)$ & $15.99(1.60)$ & $1.46(0.16)$ & $9.39(0.23)$ & $108: 11: 01$ \\
& S3 High & $0.39(0.15)$ & $0.09(0.02)$ & $0.72(0.16)$ & $2.93(1.02)$ & $129(68)$ & $9.90(2.71)$ & $1.63(0.20)$ & $8.34(0.07)$ & $93: 07: 01$ \\
& Control & $0.20(0.02)$ & $0.10(0.03)$ & $1.75(0.77)$ & $1.53(0.34)$ & $75(23)$ & $7.74(2.33)$ & $0.84(0.05)$ & $9.79(0.29)$ & $92: 09: 01$ \\
\hline
\end{tabular}

All quantified data are expressed in $\mu \mathrm{M}$. The different treatments are four combinations of salinity (S6, S3) and carbon dioxide concentrations (Amb, High). Controls denote an extra treatment (S6 Amb) without nutrient enrichment. Numbers show mean values of four replicate treatments and standard error is shown between brackets

Table 3 Experimental conditions and manipulations, including salinity, experimental temperature, total alkalinity $\left(A_{\mathrm{T}}\right)$ and $\mathrm{pH}$ total scale $\left(\mathrm{pH}_{\mathrm{T}}\right)$

\begin{tabular}{llllcl}
\hline Day & Treatment & Salinity & $\begin{array}{l}\text { Tem- } \\
\text { perature } \\
\left({ }^{\circ} \mathrm{C}\right)\end{array}$ & $A_{\mathrm{T}}\left(\mu \mathrm{mol} \mathrm{kg}{ }^{-1}\right)$ & $\mathrm{pH}_{\mathrm{T}}$ \\
\hline 0 & S6 Amb & 6.0 & 15.3 & $1523(1.6)$ & $7.59(0.03)$ \\
& S3 Amb & 3.3 & 15.3 & $824(5.6)$ & $7.51(0.03)$ \\
& S6 High & 6.1 & 15.3 & $1523(3.2)$ & $7.59(0.04)$ \\
& S3 High & 3.2 & 15.3 & $815(1.1)$ & $7.44(0.06)$ \\
& Control & 6.0 & 15.3 & $1510(0.4)$ & $7.67(0.01)$ \\
12 & S6 Amb & 6.0 & 15.3 & $1592(3.6)$ & $7.92(0.02)$ \\
& S3 Amb & 3.2 & 15.3 & $962(3.8)$ & $7.81(0.02)$ \\
& S6 High & 6.0 & 15.3 & $1629(3.6)$ & $7.66(0.05)$ \\
& S3 High & 3.2 & 15.3 & $1020(4.2)$ & $7.65(0.01)$ \\
& Control & 6.0 & 15.3 & $1582(1.9)$ & $7.87(0.02)$ \\
\hline
\end{tabular}

$\mathrm{pH}_{\mathrm{T}}$ and $A_{\mathrm{T}}$ are measured and presented at $25^{\circ} \mathrm{C}$. Data from Day 0 were obtained before bubbling started. The different treatments are four combinations of salinity (S6, S3) and carbon dioxide concentrations (Amb, High). Controls denote an extra treatment (S6 Amb) without nutrient enrichment. Numbers show mean values of four replicate treatments and standard error is shown between brackets

biovolume at the first day and $D \mathrm{~B}$ the biovolume at the end of the period, $t \mathrm{~A}$ is day $\mathrm{A}$ and $t \mathrm{~B}$ is day $\mathrm{B}$. For Day 12, species diversity was calculated by Shannon's index.

\section{Photosynthetic pigments and nodularin}

At Day 12, $100 \mathrm{ml}$ from each aquarium was filtered onto $25 \mathrm{~mm} \mathrm{GF/F} \mathrm{filters} \mathrm{(Whatman,} \mathrm{GE} \mathrm{Healthcare,} \mathrm{Chicago,}$ USA) and the filters were flash frozen in liquid nitrogen. Filters were later extracted in $100 \% \mathrm{MeOH}$, ultrasonicated, and both the extraction and HPLC analysis followed Wright and Jeffrey (1997), described in detail in Mohlin and Wulff
(2009). Pigments are expressed as concentrations (ng cell $^{-1}$ ). For aphanizophyll and 4-keto-myxoxanthophyll, the response factor for myxoxanthophyll was used.

The cyanotoxin nodularin, produced by $N$. spumigena, was analysed using HPLC according to Pattanaik et al. (2010). At Days 0 and 12, $200 \mathrm{ml}$ from each aquarium was filtered onto $25 \mathrm{~mm}$ GF/F filters (Whatman, GE Healthcare, Chicago, USA). Only intracellular nodularin was analysed. Due to concentrations at or below the detection limit, no results are presented.

\section{Photosynthetic activity}

Photosynthetic activity was estimated by variable chlorophyll fluorescence measurements in photosystem II (PSII) with a WATER-PAM chlorophyll fluorometer calibrated for cyanobacterial application (Walz Mess- und Regeltechnik, Effeltrich, Germany). Minimum fluorescence $\left(F_{0}{ }^{\prime}\right)$ was determined by applying a low level of light and the maximum fluorescence $\left(F_{\mathrm{m}}{ }^{\prime}\right)$ by exposing the sample to a short saturation pulse of measuring light $(>4000 \mu \mathrm{mol}$ photons $\mathrm{m}^{-2} \mathrm{~s}^{-1}$ for $\left.0.6 \mathrm{~s}\right)$. Variable fluorescence $\left(F_{\mathrm{v}}=F_{\mathrm{m}}{ }^{\prime}-F_{0}{ }^{\prime}\right)$ and effective quantum yield $\left(\Delta F / F_{\mathrm{m}}{ }^{\prime}\right)$ were determined for all samples.

\section{Bacterial abundance and production}

Duplicate samples from each aquarium $(1.5 \mathrm{ml})$ were fixed on Days 0, 3, 5, 9 and 12 with EM grade glutaraldehyde (Sigma-Aldrich, St. Louis, USA, 1\% final concentration) and stored at $-80{ }^{\circ} \mathrm{C}$. Bacterial abundance was determined by flow cytometry (FACSCanto II, BD Biosciences, San Jose, USA) after staining with SYBR Green I (Molecular Probes, Thermo Fisher Scientific, Waltham USA, Marie et al. 1997) using $1.0 \mu \mathrm{m}$ green fluorescent polymer microspheres (Duke 
Scientific Corporation, Thermo Fisher Scientific, Waltham USA) as internal standard in each sample. Fluorescent beads (True counts, Becton-Dickinson, Franklin Lakes, USA) were used to calibrate the flow rate.

Bacterial productivity was measured by $\left[{ }^{3} \mathrm{H}\right]$-thymidine incorporation (Fuhrman and Azam 1982) as modified for microcentrifugation by Smith and Azam (1992). From each aquarium, duplicate $1.7 \mathrm{ml}$ aliquots were incubated in darkness with $\left[{ }^{3} \mathrm{H}\right]$-thymidine (20 nM final concentration, GE Healthcare, Chicago, USA) in sterile $2.0 \mathrm{ml}$ capacity polypropylene tubes for ca. $1 \mathrm{~h}$ at in situ temperature. Samples with 5\% trichloracetic acid added prior to the addition of isotope served as blanks. Thymidine incorporation was converted to carbon production using $1.4 \times 10^{18}$ cells mole $^{-1}$ thymidine incorporated (average calculated from published Baltic Sea data, $\mathrm{SE}=0.1 \times 10^{18}$ cells mole ${ }^{-1}$ thymidine, $n=73$, HELCOM guidelines, Helsinki Commission) and a carbon content per cell of $20 \mathrm{fg}$ (Lee and Fuhrman 1987). The appropriate use of $20 \mathrm{nM}^{3} \mathrm{H}$-thymidine was confirmed by saturation curves.

\section{Stoichiometry and analyses of dissolved inorganic nutrients}

For analyses of particulate organic carbon (POC), nitrogen (PON) and phosphorus (POP), at Days 0 and 12, $100 \mathrm{ml}$ from each aquarium was filtered onto pre-combusted $\left(400{ }^{\circ} \mathrm{C}\right.$ for $4 \mathrm{~h}$ ) $25 \mathrm{~mm} \mathrm{GF} / \mathrm{C}$ filters (Whatman, GE Healthcare, Chicago, USA). The filters for POP analyses were washed with $0.1 \mathrm{M} \mathrm{HCl}$ and rinsed with Milli-Q prior to filtration. All filters were then frozen at $-20{ }^{\circ} \mathrm{C}$ and freezedried for 36 h (Heto Power Dry PL3000, Thermo Fisher Scientific, Waltham, USA). Filters for POC/PON analysis were ground (MM301, Retsch, Haan, Germany) and a subsample was carefully weighed and analysed in an elemental analyser (EA 1108 CHNS-O, Fisons Instruments, Thermo Fisher Scientific, Waltham USA) applying 2,5-bis-[5-ert.butyl-bensoaxzol-2-yl]-thiophen as a standard. POP-filters were analysed at Tvärminne Zoological Station, Finland, according to Solorzano and Sharp (1980).

Samples for determination of inorganic nitrogen (DIN, $\mathrm{NO}_{2}{ }^{-}$and $\mathrm{NO}_{3}{ }^{-}$), phosphate (DIP, $\mathrm{PO}_{4}{ }^{3-}$ ) and silicic acid (Si) concentrations $(\mu \mathrm{M})$ were filtered through $0.45 \mu \mathrm{m}$ poresize polycarbonate filters, frozen in $-80{ }^{\circ} \mathrm{C}$ until analysed using colorimetric determination performed on an autoanalyser (Grasshoff et al. 1999) at the accredited laboratory of the Swedish Meteorological and Hydrological Institute, Gothenburg (Sweden).

\section{Determination of the carbon dioxide system}

Samples for $\mathrm{pH}$ and total alkalinity $\left(A_{\mathrm{T}}\right)$ were analysed following established protocols for seawater carbonate system determination (e.g. Dickson et al. 2007). $A_{\mathrm{T}}$ was determined by potentiometric titration (Metrohm 800 Dosino and Aquatrode with Pt1000, Metrohm, Herisau, Switzerland) in an open cell with $0.05 \mathrm{M}$ hydrochloric acid (Mattsdotter-Björk et al. 2014). The precision of the $A_{\mathrm{T}}$ measurements was obtained by triplicate analysis of one sample and was estimated to ca. $\pm 3 \mu \mathrm{mol} \mathrm{kg} \mathrm{kg}^{-1}$. The accuracy of $A_{\mathrm{T}}$ was $\pm 5 \mu \mathrm{mol} \mathrm{kg} \mathrm{kg}^{-1}$ throughout the entire experiment and controlled using Certified Reference Material (CRM, batch 79) supplied by A. Dickson (San Diego, USA). pH was determined spectrophotometrically (diode-array spectrophotometer, HP8452, Hewlett-Packard, Palo Alto, USA) on the total scale $\left(\mathrm{pH}_{\mathrm{T}}\right)$ using a $2 \mathrm{mM}$ solution (salinity 6) of the sulphonephtalein dye, m-cresol purple, as an indicator (Clayton and Byrne 1993). Prior to analysis, the samples were thermostated to $\sim 25^{\circ} \mathrm{C}$ and filtered through a $0.45 \mu \mathrm{m}$ pore-size polycarbonate filter, to remove particles that could disturb the measurement. Samples were measured in a $1-\mathrm{cm}$ cell, where the temperature was measured using a thermistor with a precision of $0.1{ }^{\circ} \mathrm{C}$. The analytical precision was estimated to $\pm 0.004 \mathrm{pH}_{\mathrm{T}}$ units, which was determined by a series of ten analyses of one sample. $\mathrm{The}_{\mathrm{TH}}$ of the indicator solution was measured daily in a $0.2 \mathrm{~mm}$ quartz cell. The perturbation of seawater $\mathrm{pH}_{\mathrm{T}}$ caused by the addition of the indicator solution was calculated and corrected for using the method described in Chierici et al. (1999). $A_{\mathrm{T}}, \mathrm{pH}_{\mathrm{T}}$, salinity, temperature, DIP and Si concentration were used in a chemical speciation model (CO2SYS, Pierrot et al. 2006) to calculate $p \mathrm{CO}_{2}$, total inorganic carbon $\left(C_{\mathrm{T}}\right)$, and $\mathrm{pH}_{\mathrm{T}}$ at in situ temperature. We used the $\mathrm{CO}_{2}$-system dissociation constants by Mehrbach et al. (1973) as refit by Dickson and Millero (1987).

\section{Statistical analyses}

Data were analysed with two-way ANOVA using SPSS software (PASW Statistics ver. 18, SPSS Inc., Chicago, USA) for each sampling day. Homogeneity was tested by Cochran's test and, where needed, data were transformed according to Underwood (1997). Non-metric multidimensional scaling (nMDS) of microalgal community structure was performed on square-root-transformed relative species biovolume data from Day 12, using Bray-Curtis dissimilarity in the vegan package in R (R Core Team 2016; Oksanen et al. 2017). PERMANOVA was used for detecting differences between experimental treatments in the dissimilarity matrix, using 1000 permutations in the vegan package in R. Significant differences were set as $p<0.05$. Correlations between concentration of heterotrophic bacteria and different species of microplankton including micrograzers (i.e. ciliates) were performed with Pearson correlation, using SPSS software as above. 


\section{Results}

In our study, salinity seemed more important than $p \mathrm{CO}_{2}$; however, possible concomitant effects of diluted nutrient concentrations will be discussed. For $p \mathrm{CO}_{2}$, only effects on biovolumes of Dolichospermum spp. and biomass of heterotrophic bacteria were observed. No interaction effects of salinity and $p \mathrm{CO}_{2}$ were found. The biovolume of the toxic Nodularia spumigena was negatively affected by salinity 3 , and during the ca 2 weeks experiment the initially dominating Aphanizomenon sp. was replaced by Dolichospermum spp. The A1FI scenario (salinity 3 and $\left.p \mathrm{CO}_{2} 960 \mu \mathrm{atm}\right)$ resulted in increased biomass of Dolichospermum spp. Although time was not considered a treatment factor for the experimental design, still some differences irrespective of treatment were apparent in the different variables measured ("Successional changes irrespective of treatment", see below).

\section{Treatment effects}

\section{Biomass and community composition}

No interaction effects were found, but effects of salinity and $p \mathrm{CO}_{2}$, respectively, were observed. On Day 12 , total phytoplankton biomass, approximated by $\operatorname{chl} a$, was significantly higher in salinity 3 compared to salinity $6\left(F_{(1,12)}=6.63\right.$, $p=0.024$, two-way ANOVA, Table 1). The microalgal community structure, defined as the relative species biovolume, varied significantly between the salinity treatments Day 12 (pseudo- $F_{(1,12)}=14.2, p<0.001$, PERMANOVA, Fig. 1). These differences were further investigated for specific taxa; Dolichospermum spp. showed significantly higher biovolumes in treatments with salinity 3 compared to present day salinity of 6 (Fig. 2). The effect of lower salinity persisted throughout the experiment (Day $12 ; F_{(1,11)}=10.40$, $p=0.007$, two-way ANOVA). In addition, elevated $p \mathrm{CO}_{2}$ stimulated the total biovolume of Dolichospermum spp. (Day 12; $F_{(1,11)}=5.26, p=0.04$, two-way ANOVA), with the highest values found for the treatment with salinity 3 and
Fig. 1 Non-metric multidimensional scaling of relative species abundance on Day 12, displayed with sample (a) and species (b) scores. The dissimilarity matrix was calculated with Bray-Curtis dissimilarity. PERMANOVA revealed that salinity treatment had a significant effect on the species composition (pseudo$\left.F_{(1,12)}=14.2, p<0.001\right)$, which is illustrated with the grey ellipses in (a)
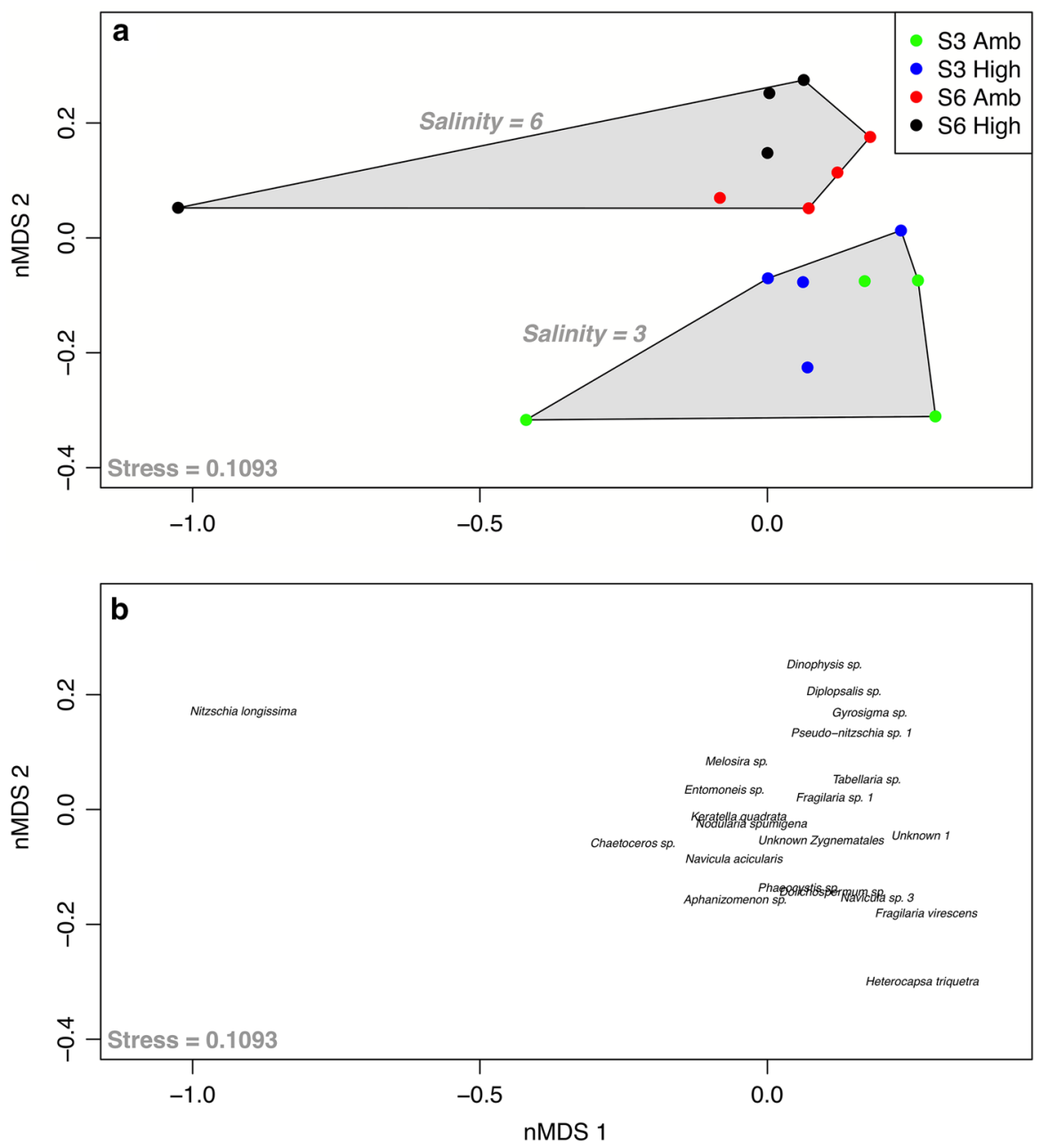

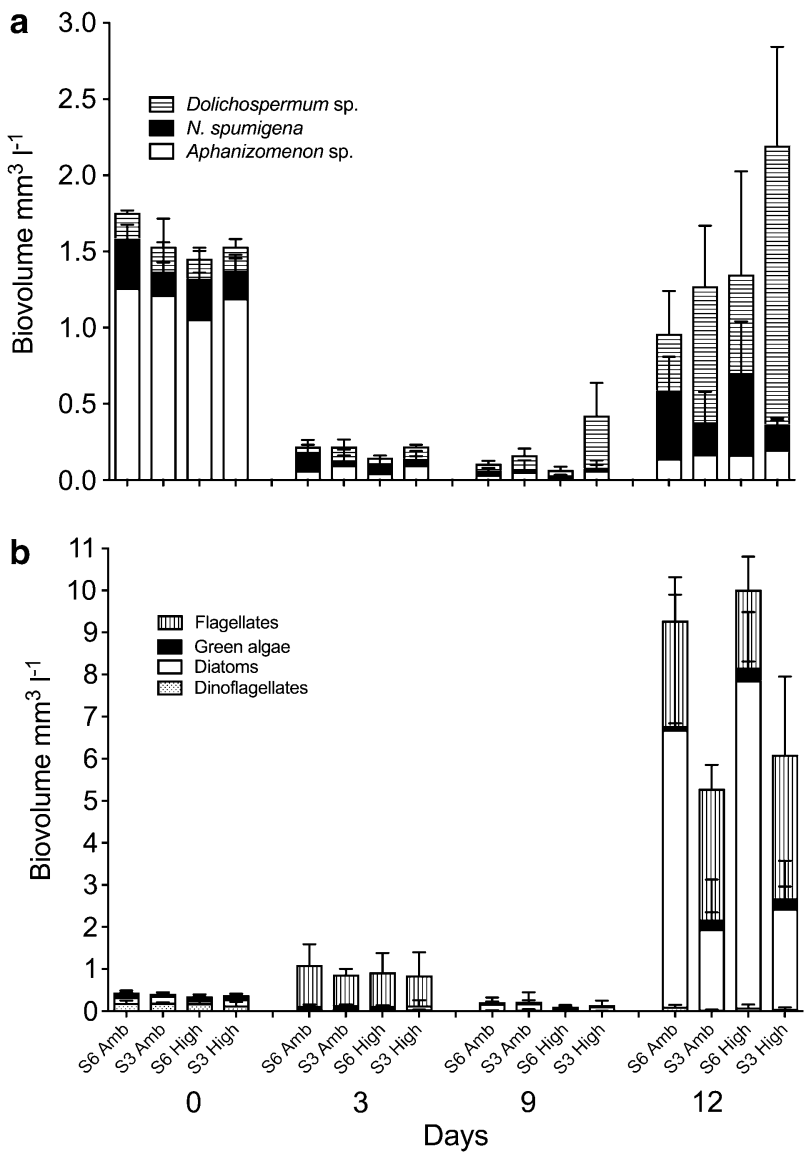

Fig. 2 Biovolumes of diazotrophic cyanobacteria (a) and (b) biovolumes of flagellates, green algae, diatoms and dinoflagellates. The different treatments are four combinations of salinity (S6, S3) and carbon dioxide concentrations (Amb, High). Vertical lines show standard deviation $(n=4)$

elevated $p \mathrm{CO}_{2}$ (Fig. 2). For the toxic N. spumigena, lower biovolumes were found in salinity 3 compared to salinity 6 (Day $12 ; F_{(1,11)}=7.21, p=0.020$, two-way ANOVA, Fig. 2). The biovolumes of dinoflagellates and diatoms were negatively affected by reduced salinity and showed higher biovolumes in salinity 6 by Day $12\left(F_{(1,12)}=8.86\right.$, $p=0.012$ (dinoflagellates); $F_{(1,12)}=13.11, p=0.004$ (pennate diatoms); $F_{(1,12)}=33.04, p<0.001$ (centric diatoms); twoway ANOVA, Fig. 2). No significant treatment effects were observed for specific growth rate $\left(\mu\right.$ day $\left.^{-1}\right)$ of cyanobacteria except for Dolichospermum spp., with initially (Days 0 to 3 ) lower growth rate in salinity 6 compared to salinity 3 $\left(F_{(1,11)}=11.61, p=0.006\right.$, two-way ANOVA $)$. The highest growth rate of 1.2 day $^{-1}$ was observed for $N$. spumigena between Days 9 and 12. Shannon's index showed that the highest biodiversity (1.40) was found at salinity 6 (Day 12; $F_{(1,12)}=17.34, p=0.001$, two-way ANOVA).

The concentration of carotenoids confirmed the results from phytoplankton biovolumes with an overall dominance
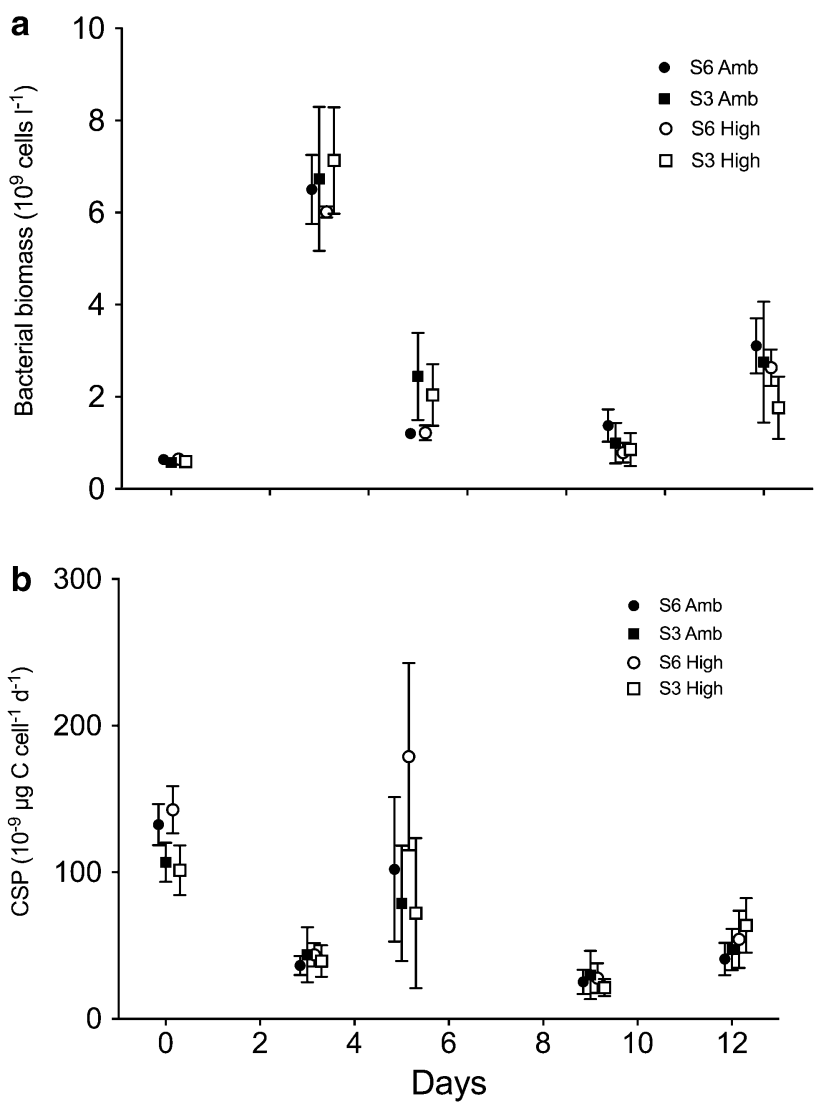

Fig. 3 Bacterial cell numbers (a) and (b) cell-specific bacterial productivity (CSP, estimated by thymidine uptake rates). The different treatments are four combinations of salinity (S6, S3) and carbon dioxide concentrations (Amb, High). Vertical lines show standard deviation $(n=4)$. NB: Data points are positively nudged on the $x$ axis to properly display the error bars

of pigments specific for cyanobacteria; myxoxanthophyll, canthaxanthin and echinenone. For these pigments, higher concentrations were found in salinity 3 compared to salinity 6 (Table 1). Fucoxanthin, here a proxy for diatoms, showed no treatment effects.

Total biovolumes of micrograzers were not affected by the treatments, but for ciliates higher biovolumes were found in salinity of 6 compared to salinity 3 (Day $\left.12, F_{(1,12)}\right)=5.24$, $p=0.041$, two-way ANOVA, Table 1). By Day 12, the biomass of heterotrophic bacteria was significantly higher in present day conditions of salinity 6 and $p \mathrm{CO}_{2} 380 \mu \mathrm{atm}$, respectively $\left(F_{(1,28)}=5.20, p=0.030 ; F_{(1,28)}=7.39, p=0.011\right.$, two-way ANOVA, Fig. 3). As a consequence of dilution to reach target salinity of 3 , significant treatment effects were observed already at Day 0 , with higher concentrations in salinity $6\left(F_{(1,28)}=64.29, p<0.000\right.$, two-way ANOVA); however, the difference was only $10 \%$. Neither bacterial productivity nor cell-specific productivity (Fig. 3) showed any treatment effects by Day 12, but initially both were higher at the present 
day salinity of $6\left(F_{(1,28)}=45.32, p=0.000\right.$ and $F_{(1,28)}=19.28$, $p=0.001$, respectively, two-way ANOVA).

\section{Stoichiometry and dissolved inorganic nutrients}

No significant treatment effects were observed for either concentrations or elemental ratios (POC, PON and POP, Table 2). Treatment effects were observed for DIN, DIP and Si concentrations (Table 2). Due to dilution, dissolved inorganic nutrient concentrations were higher in aquaria with salinity 6 at Day 0 (Table 2). At Day 0 (before adding $\mathrm{CO}_{2}$ ), effects of both salinity and $p \mathrm{CO}_{2}$ were observed in the DIN:DIP ratio with a significantly higher ratio at salinity 6 in $p \mathrm{CO}_{2} 380 \mu \mathrm{atm}$ (Table 2). At salinity 6, Si decreased at a higher daily rate between Days 5 and 9 compared to Days 3-5 $\left(F_{(1,11)}=26.54\right.$, $p=0.0009$, two-way ANOVA, not shown). The Si decline was concomitant with increasing diatom biovolumes (Fig. 2). Furthermore, at Day 0, significant treatment effects were observed in the elemental ratio DIN:DIP:Si; at salinity 6 the $p \mathrm{CO}_{2} 380$ $\mu$ atm treatment showed a higher ratio than the $p \mathrm{CO}_{2} 960 \mu \mathrm{atm}$ treatment, and at $p \mathrm{CO}_{2} 960 \mu \mathrm{atm}$, a higher ratio was found in salinity 3 compared with salinity 6 . No statistically significant treatment effects remained at Day 12.

\section{Carbon dioxide system}

Initially (Day 0, before adding $\mathrm{CO}_{2}$ ), average $\mathrm{pH}_{\mathrm{T}}$ in salinity 6 was 7.59 (SE 0.01) and in salinity 3, 7.47 (SE 0.03) (no significant treatment effects). From Days 3 to 12 , the high $p \mathrm{CO}_{2}$ treatment had significantly higher $p \mathrm{CO}_{2}$ compared to the 380 $\mu$ atm treatment, but differed from target $p \mathrm{CO}_{2}$. At Day 12, $p \mathrm{CO}_{2}$ for the $380 \mu \mathrm{atm}$ treatment at salinity 6 was $403 \mu \mathrm{atm}$ (SE 18) and for salinity 3, $342 \mu$ atm (SE 16). For the high $p \mathrm{CO}_{2}$ treatment, mean $p \mathrm{CO}_{2}$ was $833 \mu \mathrm{atm}$ (SE 108) at salinity 6 , and $579 \mu \mathrm{atm}$ (SE 39) at salinity 3 . The continuous supply of $\mathrm{CO}_{2}$ complicates interpretation of changes in $\mathrm{pH}$ in relation to treatments. Initial $A_{\mathrm{T}}$ was on average 1523 and $820 \mu \mathrm{mol} \mathrm{kg}{ }^{-1}$ at salinities of 6 and 3 , respectively (Table 3 ). The difference was due to the initial dilution performed to reach target salinity. At Day $12, A_{\mathrm{T}}$ in the $380 \mu \mathrm{atm}$ treatment was $1592 \mu \mathrm{mol} \mathrm{kg}-1$ (SE 4) for salinity 6 , and $962 \mu \mathrm{mol} \mathrm{kg}^{-1}$ (SE 4) for salinity 3 (Table 3). For the high $p \mathrm{CO}_{2}$ treatment, corresponding values were $1629 \mu \mathrm{mol} \mathrm{kg}^{-1}$ (SE 4) and $1020 \mu \mathrm{mol} \mathrm{kg}{ }^{-1}$ (SE 4), for salinity 6 and 3 , respectively (Table 3 ). The $A_{\mathrm{T}}$ increase was generally higher in the high $\mathrm{CO}_{2}$ treatments, regardless of salinity.

\section{Successional changes irrespective of treatment}

\section{Biomass and community composition}

Changes with time were found in the structure of the microbial community, indicating a successional pattern during the experiment (not statistically tested). For phytoplankton biomass, proxied by total cell biovolumes and chl $a$ concentrations, a general decline from initial values was followed by an increase until termination of the experiment by Day 12 (Table 1, Fig. 2). However, total biovolume of dinoflagellates decreased from Days 0 to 12 (Fig. 2). The most striking result was the shift in cyanobacteria composition where Aphanizomenon sp. decreased from the initial 87 to $15 \%$ and Dolichospermum spp. increased from 11 to $82 \%$ of the total filamentous cyanobacterial biovolumes. The successional pattern in phytoplankton biovolumes was mirrored by the concentration of heterotrophic bacteria; however, when phytoplankton biovolumes decreased the concentration of heterotrophic bacteria increased (Figs. 2, 3). This trend was consistent until Day 9. Between Days 9 and 12 the biomass of both phytoplankton and bacteria increased. Bacterial productivity followed the bacterial biomass with the exception that cell-specific productivity differed from bacterial biomass and declined from Days 0 to 3 (Fig. 3). At Day 12, a significant positive correlation (Pearson, $r^{2}(15)=0.647$, $p=0.009$ ) between the concentration of heterotrophic bacteria and $N$. spumigena was found. An example of epiphytic bacteria associated with $N$. spumigena is shown in Fig. 4. There was no significant correlation between heterotrophic bacterial concentration and concentration of any other organisms, such as other cyanobacteria, dinoflagellates, diatoms or ciliates.

\section{Stoichiometry and dissolved inorganic nutrients}

POC and PON concentrations generally decreased over time, while POP concentrations increased (Table 2). For all treatments, POC:POP and PON:POP had generally lower

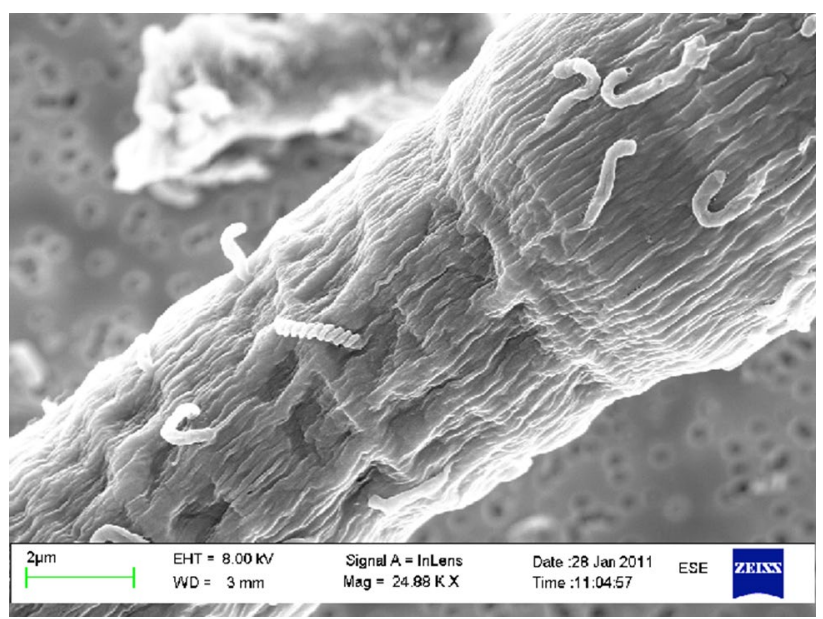

Fig. 4 The filamentous cyanobacteria Nodularia spumigena with associated heterotrophic bacteria. Effects of climate change on the autotrophic community may have indirect effect on closely associated heterotrophic bacteria and their biogeochemical interactions 
relative Redfield ratios of 106 and 16, respectively (Day 12). In contrast, POC:PON ratios were higher than the Redfield ratio of 6.6 for all treatments throughout the experiment (Table 2). The inorganic nutrient concentrations DIN, DIP and Si decreased between Days 0 and 3 (all treatments, not shown). DIN decreased drastically between Days 0 and 3 , and remained low $(<0.4 \mu \mathrm{M})$ throughout the remaining part of the experiment. Despite the addition of DIN, values were similar to the control treatment where no inorganic nutrients were added. The DIN:DIP ratio decreased in all treatments, including the control treatment, from Day 0 to Day 12 , again showing nitrogen limitation (ratio $<3$, Redfield $=16$ ). Si decreased continuously throughout the experiment and at a faster rate towards the end of the experiment (from 0.5-1.1 $\mu \mathrm{M}$ Day 9, to 0.6-0.8 $\mu \mathrm{M}$, Day 12), in concert with the increasing diatom biovolumes (Fig. 2). Limitation of $\mathrm{Si}$ was confirmed by the increased DIN:DIP:Si ratios in all treatments from Day 0 to Day 12; however, all treatments including the control treatment showed Si limitation already on Day 0 (ratio above 1.1; Brzezinski 1985).

\section{Carbon dioxide system}

The $\mathrm{pH}$ increased in all treatments during the experiment (Table 3 ), indicating $\mathrm{CO}_{2}$ uptake (net primary production) further supported by the decrease in $p \mathrm{CO}_{2}$ for all treatments (despite the continuous supply of $\mathrm{CO}_{2}$ to the aquaria). $A_{\mathrm{T}}$ increased in all treatments over time (Table 3 ). $A_{\mathrm{T}}$ is not affected by changes in $p \mathrm{CO}_{2}$ and observed changes are likely caused by net assimilation of $\mathrm{NO}_{3}^{-}$and $\mathrm{H}^{+}$(e.g. protein synthesis during photosynthesis).

\section{Diurnal variations}

\section{Photosynthetic activity and $\mathrm{pH}$ in experimental aquaria}

During the hourly measurements over $30 \mathrm{~h}$, no significant treatment effects were found in $\Delta F / F_{\mathrm{m}}{ }^{\prime}$. However, all treatments showed dynamic response to radiation saturation where $\Delta F / F_{\mathrm{m}}{ }^{\prime}$ was depressed from early morning to around 17:00 (solar time). From late afternoon, the radiation stress diminished and $\Delta F / F_{\mathrm{m}}{ }^{\prime}$ returned to original values (Fig. 5). Also, a clear diurnal $\mathrm{pH}$ cycle was observed, with lowest values during night/early morning (7.57) and highest values in the evening (7.92) (Fig. 6).

\section{Diurnal in situ variability of $\mathrm{pH}$ and $\mathrm{pCO}_{2}$}

Samples were taken every second hour for a 24 -h period directly in situ to observe the natural variability outside the aquaria. We found a clear diurnal cycle related to $\mathrm{CO}_{2}$ uptake during photosynthesis, and $\mathrm{pH}$ varied from 7.79 early in the morning to 8.42 in the late afternoon (Fig. 6). The

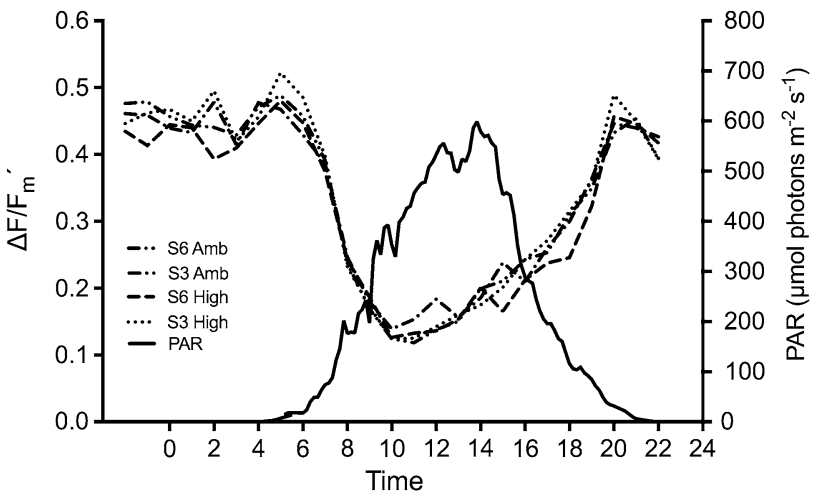

Fig. 5 Hourly measurements of effective quantum yield $\left(\Delta F / F_{\mathrm{m}}{ }^{\prime}\right)$ during $30 \mathrm{~h}$ under ambient PAR $(400-700 \mathrm{~nm})$ conditions. Active down-regulation of photosynthesis is observed during midday trough $\Delta F / F_{\mathrm{m}}{ }^{\prime}$ depression in all treatments. The different treatments are four combinations of salinity (S6, S3) and carbon dioxide concentrations (Amb, High)

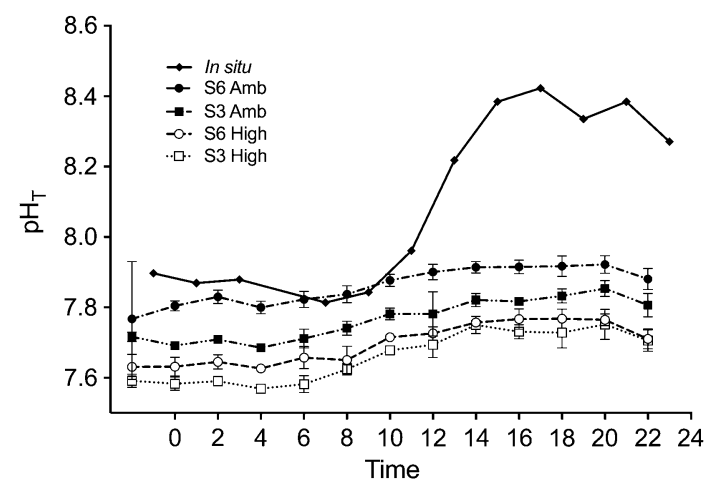

Fig. 6 Variation in $\mathrm{pH}_{\mathrm{T}}$ over $24 \mathrm{~h}$. The continuous bubbling of $\mathrm{CO}_{2}$-enriched synthetic air provides a fluctuating $\mathrm{pH}$ during the diurnal cycle of primary production. The different treatments are four combinations of salinity (S6, S3) and carbon dioxide concentrations in $\mu \mathrm{atm}$, (Amb, High) plus in situ sea surface values. Vertical lines show standard deviation $(n=4)$

opposite pattern was observed for $p \mathrm{CO}_{2}$ : the lowest value $118 \mu \mathrm{atm}$ in late afternoon and the highest, $570 \mu \mathrm{atm}$ in night/early morning. Mean $A_{\mathrm{T}}$ in situ was $1498 \mu \mathrm{mol} \mathrm{kg}-1$ (SE 4).

\section{Radiation and temperature}

The intensities of PAR and UV-A during the experimental period are shown in Fig. 7. Initially, sunny conditions were followed by cloudy days from Days 7 to 12 . A sunny day, PAR in the water outside Askö Laboratory measured $450 \mu \mathrm{mol}$ photons $\mathrm{m}^{-2} \mathrm{~s}^{-1}$ at $1 \mathrm{~m}$ depth, while cloudy days showed typical intensities of $180 \mu \mathrm{mol}$ photons $\mathrm{m}^{-2} \mathrm{~s}^{-1}$. Experimental temperatures followed fluctuations in ambient water surface temperatures. 


\section{Discussion}

Our aim was to test the combined impact of decreased salinity (from 6 to 3 ) and elevated $p \mathrm{CO}_{2}$ (from $380 \mu$ atm to 960 $\mu \mathrm{atm}$ ), following the A1FI scenario (Meehl et al. 2007) on a natural Baltic Sea microbial community, focusing on filamentous cyanobacteria during the summer bloom. No interaction effects of salinity and $p \mathrm{CO}_{2}$ were found. As a driver of the microbial community structure and biomass, salinity seemed more important than $p \mathrm{CO}_{2}$; however, possible concomitant effects of diluted nutrient concentrations will be discussed. Long-term effects of the experimental treatments need to be further studied, and indirect effects of the lower salinity treatments could not be ruled out. The biomass of the toxic $N$. spumigena was negatively affected by the reduced salinity, and during the experiment the initially dominating Aphanizomenon sp. was replaced by Dolichospermum spp. The shift between Aphanizomenon sp. and Dolichospermum spp. was also observed in situ. Heterotrophic bacteria seemed more affected by the phytoplankton biomass than by the experimental treatments. The highest biodiversity (1.40, by Shannon's index) was found at salinity 6 .

Dilution experiments in natural microbial communities are indeed a challenge, particularly in combination with acidification. We are aware that dilution with Milli-Q water does not mimic natural conditions and might have caused indirect treatment effects. Nevertheless, alternatives such as dilution with tap water or lake water were ruled out due to the addition of other compounds and different ions, with potential effects on the carbonate system, e.g. $A_{\mathrm{T}}$. Dilution of the ambient treatment followed by addition of salts was considered, but avoided because the addition of commercially available salts, different from the ions found in the Baltic

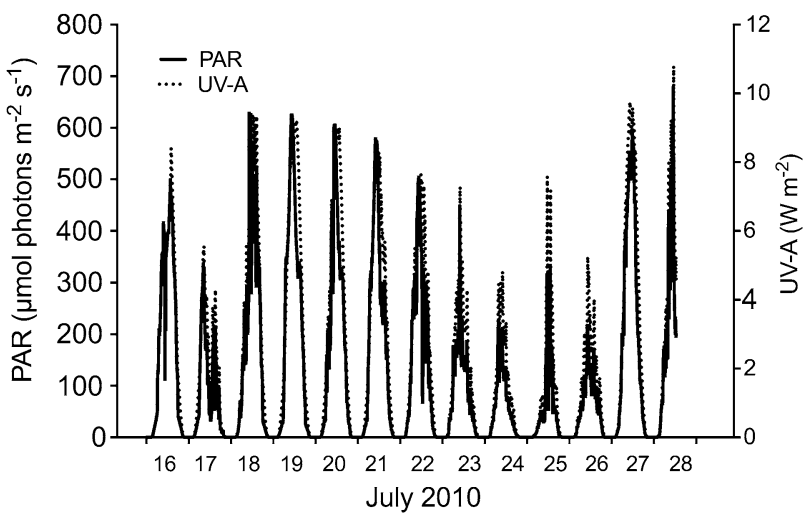

Fig. 7 Daily variations of photosynthetic active radiation (PAR, 400$700 \mathrm{~nm}$ ) and ultraviolet-A radiation (UV-A, 320-400 nm) during the experimental period. The aquaria and light sensors were placed under a mesh to simulate light intensities experienced in the surface water of the Baltic Sea (see "Experimental setup")
Sea, had introduced yet another treatment factor. Despite the reduced buffering capacity $\left(A_{\mathrm{T}}\right)$, we did not find any significant effects of $p \mathrm{CO}_{2}$ and we believe that it strengthens our arguments that the carbonate system was not that important in this study. Despite the addition of nutrients, the dilution resulted in lower nutrient concentrations in the lower salinity treatments. This makes it difficult to clearly separate a salinity effect from a nutrient effect. Nevertheless, the most pronounced increase in biomass was between Day 9 and Day 12 where elemental ratios (and nutrient concentrations) in all treatments showed a noticeable DIN and $\mathrm{Si}$ limitation. Our focus was diazotrophic cyanobacteria and the setup was advantageous for this group. However, also diatom biomass increased and was higher in the salinity 6 treatments on Day 12, in spite of DIN and Si limitation already on Day 9 (DIN:DIP ratio < 1.5; DIN:DIP:Si ratio < 1.9). Therefore, we argue that salinity did have an effect.

Both dinoflagellates and diatoms were negatively affected by lower salinity; thus, cyanobacteria like Dolichospermum spp. could get yet another competitive advantage in a future Baltic Proper. Our results suggest that the toxic N. spumigena will not grow as well in a lower salinity environment but, on the other hand, the increasing biovolume by Day 12 indicates acclimation. In laboratory studies, optimum salinity for growth of $N$. spumigena ranges from 7 (MazurMarzec et al. 2005) to 10 (Lehtimäki et al. 1997), but the species also grow well at both salinities 4 and 7 (Karlberg and Wulff 2013). For Aphanizomenon sp., Lehtimäki et al. (1997) concluded that Aphanizomenon sp. preferred salinity $0-5$ over salinity 10 and 30, and when comparing salinity 7 and 4, no effects on biovolumes of Aphanizomenon sp. were detected (Karlberg and Wulff 2013). Elevated $p \mathrm{CO}_{2}$ had a positive effect on total biovolume for Dolichospermum spp. with the highest values found in the treatment with salinity 3 and elevated $p \mathrm{CO}_{2}$. For the toxic N. spumigena, lower biovolumes were found in salinity 3 compared to salinity 6, implying a less toxic future Baltic Sea. Moreover, the amount of fixed $\mathrm{N}_{2}$ and released $\mathrm{NH}_{4}{ }^{+}$might increase, since Dolichospermum spp. showed relatively higher $\mathrm{N}_{2}$-fixation rates compared to $N$. spumigena (Klawonn et al. 2016), with a positive feedback mechanism on the microbial loop. Effects on copepods were revealed in a summer field survey where $N$. spumigena had positive effects on copepod egg production and egg viability, while Aphanizomenon sp. showed a negative relationship with egg viability (Hogfors et al. 2014. Thus, through lower biovolumes of N. spumigena, a future a less saline Baltic Proper could imply a less positive environment for copepods. In our study, no effect of the elevated $p \mathrm{CO}_{2}$ was observed for $N$. spumigena and Aphanizomenon sp., contradictory to Eichner et al. (2014b), showing a decreased growth rate in elevated $p \mathrm{CO}_{2}$ for $N$. spumigena and an increased growth rate at elevated $p \mathrm{CO}_{2}$ by Wannicke et al. (2012). Moreover, Brutemark et al. (2015) 
reported that no effects on growth of Dolichospermum spp. were found when exposed to low $\mathrm{pH} / \mathrm{high} \mathrm{CO}_{2}$. However, the latter three studies were performed on single-species cultures and, as shown by Mohlin et al. (2012), under stressful conditions growth rate of $N$. spumigena was stimulated by the presence of Aphanizomenon sp., further complicating interpretations from single-species experiments. Micrograzers were not affected by $p \mathrm{CO}_{2}$, which is consistent with results by Aberle et al. (2013) from a coastal planktonic community. $N$. spumigena has been assumed to be the only species of the three dominating filamentous cyanobacteria species in the Baltic Proper that produces toxin, but also Dolichospermum spp. has been proposed as a potential toxin producer in different parts of the Baltic Sea (Sivonen et al. 2007). The nodularin concentration has earlier shown to be affected by salinity (Lehtimäki et al. 1997; Mazur-Marzec et al. 2005). We measured nodularin on Days 0 and 12, but concentrations were always below or very close to the detection limit of the instrument. It is therefore unknown whether the treatments had any effects on the toxin concentration.

The specific treatment effects on heterotrophic bacteria (higher biomass in present day conditions) are difficult to distinguish in experiments with natural communities where bacteria cannot be tested separately from autotrophs. In our setup, the bacteria sampled were associated with the phytoplankton. The abundance of heterotrophic bacteria was, for example, positively correlated to $N$. spumigena and a negative treatment effect on this species would, thus, negatively affect the associated bacteria. Furthermore, environmental conditions and treatments stressing the phytoplankton community could result in more dissolved organic carbon (DOC) available for the heterotrophic bacteria, leading to increased abundance (like we observed between Days 0 and $3)$. This was observed in a large ocean acidification study where the heterotrophic activity was closely coupled to the primary productivity and release of DOC (Engel et al. 2013). In another mesocosm study, Grossart et al. (2006) report the indirect effects of $p \mathrm{CO}_{2}$ on heterotrophic bacteria mediated by the phytoplankton community. On the other hand, Endres et al. (2014) found a stimulation of bacterial growth at elevated $p \mathrm{CO}_{2}$ (lower $\mathrm{pH}$ ). This stimulation was attributed to increased availability of gel particles as food source and substrate, plus enhanced enzymatic hydrolysis of organic matter. In the Baltic, however, Lindh et al. (2013) found that ocean acidification (lowering of $0.4 \mathrm{pH}$ units) did not affect the biomass of a heterotrophic bacterial assemblage, neither alone or in combination with increased temperature, but ocean acidification in combination with increased temperature resulted in a shift in the bacterial community composition. These results highlight the complexity of unravelling the effects of climate change on natural microbial communities and further stress the importance of a multifactorial experimental approach. Moreover, salinity has been shown to affect both functional performance and composition of bacterial communities regardless of DOC composition (Langenheder et al. 2003). The heterotrophic bacterial assemblage in the Baltic Proper is typically an assemblage adapted to this brackish environment with a pronounced influence of freshwater groups and lack of typical marine species (Riemann et al. 2008; Andersson et al. 2010; Herlemann et al. 2011). A future less saline Baltic Proper could increase the proportion of freshwater groups with yet unknown consequences for the marine food web (e.g. Herlemann et al. 2011); however, Nydahl et al. (2013) suggest that in a future warmer and wetter climate, the heterotrophic bacterial activity will increase, with increased coastal hypoxia as a possible outcome. The DOC pool in our experiment was initially diluted in the low-salinity treatments, potentially reducing substrate access for heterotrophic bacteria. Indeed, bacterial productivity appeared higher initially in the highsalinity treatments, but no significant differences remained after 12 days between the high- and low-salinity treatments, indicating that other factors than carbon availability limited bacterial growth.

The highest biodiversity (by Shannon's index) was found at salinity 6, implying that a future Baltic Proper may host a lower phytoplankton biodiversity. Our result is a snapshot in time, but considering the biodiversity gradient in the Baltic Sea, following the salinity gradient with higher biodiversity in the south, which is worth emphasizing. Lower biodiversity generally implies a decreased resilience towards environmental (including anthropogenic) stress; however, if all species within a functional group respond similar to pressure, a higher biodiversity will not offer resilience (Hughes et al. 2005). For the type of microbial communities studied, the close coupling between phytoplankton and heterotrophic bacteria further complicates interpretation of experimental treatment effects. For heterotrophic bacteria, the experimental treatments (salinity and $p \mathrm{CO}_{2}$ ) from an ecological perspective could be considered as press disturbance, where the shift in phytoplankton composition and biomass was comparable to pulse disturbance (Shade et al. 2012) with different implications for the heterotrophic bacterial community resistance and/or resilience (Baho et al. 2012; Shade et al. 2012).

In our study, $A_{\mathrm{T}}$ increased slightly during the experiment. Addition of $\mathrm{CO}_{2}$ does not affect $A_{\mathrm{T}}$, but the exudation of organic substances containing basic functional groups could explain the observed pattern (cf Kim and Lee 2009). Thus, to better describe the carbonate system, other parameters such as dissolved inorganic carbon might be preferred in similar experiments (Gattuso et al. 2010; Schulz and Riebesell 2013). To reach target salinities, seawater of higher salinity was mixed with Milli-Q water, thus reducing the buffering capacity of the experimental water. Consequently, the $A_{\mathrm{T}}$ of the experimental water differed from that of Baltic seawater 
of similar salinities. The reduced buffering capacity could lower $\mathrm{pH}$, but was not expected to affect the microorganisms in our experiment (cf Ploug 2008; Karlberg and Wulff 2013), and the $\mathrm{pH}$ change in situ over $24 \mathrm{~h}$ was between 7.79 and 8.42. In a yet to be submitted study on another Baltic microbial community (Karlberg et al. unpublished), $A_{\mathrm{T}}$ was reduced from approximately $1500-1000 \mu \mathrm{mol} \mathrm{kg}^{-1} \mathrm{SW}$, with no effect on the microorganisms. In the aquaria, the diurnal variability in photosynthesis (i.e. carbon uptake) resulted in large variations in $p \mathrm{CO}_{2}$ levels, despite the constant supply with $\mathrm{CO}_{2}$-enriched air. Our measurements were performed in the morning and provide a snapshot of the carbonate system. Large variations of $p \mathrm{CO}_{2}$ due to the diurnal cycle of primary productivity have also been observed in coastal surface waters (Borges and Frankignoulle 1999; Fransson et al. 2004; Schulz and Riebesell 2013). Despite the complexity, maintaining a constant $p \mathrm{CO}_{2}$ in the medium lacks ecological relevance when performing $\mathrm{CO}_{2}$ enrichment experiments on primary producers. Our experimental setup generates a diurnal variable $p \mathrm{CO}_{2}$, fluctuating with similar wavelengths as in situ conditions. Therefore, bubbling with $\mathrm{CO}_{2}$-enriched air is an advantageous method when studying organisms capable of substantial $\mathrm{CO}_{2}$ perturbation (Gattuso et al. 2010; Karlberg and Wulff 2013; Torstensson et al. 2013, 2015). Also, due to the high $\mathrm{CO}_{2}$ uptake, the $p \mathrm{CO}_{2}$ differed from the targeted level of $960 \mu \mathrm{atm}$ (projected for future atmospheric $p \mathrm{CO}_{2}$ ). Hence, a more intense bubbling to keep a $p \mathrm{CO}_{2}$ of $960 \mu$ atm had stimulated an unrealistically high $\mathrm{CO}_{2}$ sink in the system. Forcing very acidic conditions to a system with high primary productivity will overestimate the effects of ocean acidification, as these blooming surface communities will never experience those high levels during the climate scenario that we simulated (due to intense primary productivity). In our opinion, it is more realistic to start with high $\mathrm{CO}_{2}$ levels before the bloom and let it decrease as the bloom develops, just as in natural systems. The headspace will still represent simulated atmospheric levels of $\sim 960 \mu \mathrm{atm}$. Furthermore, we performed a pilot study to choose an appropriate flow rate and the higher flow rate was chosen to somewhat compensate for the increased primary productivity over time. Again, to illustrate the diurnal changes in the treatment aquaria and in situ, we performed ca. $30 \mathrm{~h}$ measurements where samples were taken and analysed every second hour.

Similar to our study, in a post-bloom Baltic microplankton assemblage, no $\mathrm{CO}_{2}$-related effects in neither inorganic nor organic $\mathrm{N}$ pool sizes, or particulate matter $\mathrm{N}: \mathrm{P}$ stoichiometry were found (Paul et al. 2016). Although nutrient levels were low by Day 12, in situ nutrient concentrations (DIN, DIP) in the surface water at the sampling site were lower with typical values of $0.02-0.06 \mu \mathrm{M}$ (DIN) and $0.02 \mu \mathrm{M}$ (DIP). Our Si concentrations by Day 12, however, were generally lower compared to in situ values of $6-8.6 \mu \mathrm{M}$. Apart from our experimental treatments, the Baltic Proper is under pressure with increased internal loading of phosphorus, lowering DIN:DIP ratios which presumably benefit diazotrophic cyanobacteria (Wasmund 1997; Vahtera et al. 2007a). In our study, nutrients without nitrogen and silicate were added to further mimic summer conditions in the Baltic Proper without introducing DIP limitation, and DIN:DIP ratios at Days 3 to $12(<5)$ confirmed nitrogen limitation in all aquaria. However, also DIP decreased, which was most likely caused by the P-storing abilities of the cyanobacteria (Vahtera et al. 2007b; Mohlin and Wulff 2009; Olofsson et al. 2016). Again, despite the Si limitation indicated by the DIN:DIP:Si ratios, both cell numbers and biovolume of diatoms increased by the end of the experiment. It is also worth noticing that the highest chl $a$ concentrations by Day 12 was found in the treatment with salinity 3 and $p \mathrm{CO}_{2} 960$ $\mu \mathrm{atm}$, that is, a treatment with the lowest initial nutrient concentrations.

Effects of increased temperature were not addressed in this study, but is an additional potential stress factor for the Baltic microbial community. For cyanobacteria, it is proposed that an elevated temperature will give cyanobacteria a competitive advantage over other phytoplankton groups (Paerl and Huisman 2008). Baltic filamentous cyanobacteria have been shown to benefit from elevated temperatures both in laboratory studies (e.g. Karlberg and Wulff 2013) and in models (Hense et al. 2013).

Conclusively, elevated $p \mathrm{CO}_{2}$ had no significant effects on the natural microplanktonic community except for higher biovolume of Dolichospermum spp. and lower biomass of heterotrophic bacteria. At the end of experimental period, heterotrophic bacteria were correlated to $N$. spumigena. Consistent with our findings, results from the large mesocosm experiment in the Gulf of Finland 2012 (Hornick et al. 2017; Lischka et al. 2017) highlights the complexity of studying plankton community responses to increased $p \mathrm{CO}_{2}$ levels. Considering the Baltic Proper, we do not expect any dramatic effects of increased $p \mathrm{CO}_{2}$ in combination with decreased salinity on the microplanktonic food web, but effects on additional size classes and trophic levels were not a part of this study. Lower salinity significantly affected cyanobacteria together with biovolumes of dinoflagellates, diatoms, ciliates and heterotrophic bacteria, with higher biovolume of Dolichospermum spp. and lower biovolume of $N$. spumigena, dinoflagellates, diatoms, ciliates and heterotrophic bacteria in reduced salinity. Although the salinity effects on diatoms were apparent, they could not clearly be separated from the influence of inorganic nutrients. In addition, we found a clear diurnal cycle in $\Delta F / F_{\mathrm{m}}{ }^{\prime}$ and $\mathrm{pH}$, but without significant treatment effects and also in situ we observed the same diurnal pattern $\left(p \mathrm{CO}_{2}, \mathrm{pH}\right)$. Our study lasted 12 days, allowing for several generations of the organisms studied, but can still be considered a short time study. For example, in a laboratory study over 7 months, 
Torstensson et al. (2015) concluded that long-term acclimation was crucial for the diatom studied. However, any experimental design implicates choices with potentially associated biases. To conclude with a remark from Riebesell and Gattuso (2015) with respect to ocean acidification research "The paramount challenge for our research community will therefore be to assimilate the growing knowledge in each of these diverging research branches into an integrated assessment of short- to long-term responses to multiple drivers and their underlying mechanisms at the level of organisms, populations, communities and ecosystems." Thus, we believe that our study can add one piece to the complicated puzzle to reveal the combined effects of increased $p \mathrm{CO}_{2}$ and reduced salinity levels on the Baltic microplanktonic community.

Acknowledgements This study was supported by Oscar and Lili Lamm Foundation, The Swedish Research Council (VR No 2007-8365) and the Swedish Institute (scholarship for F. S. Steinhoff). We thank M. Heldal and E. Erichsen, Bergen University, for assisting M. Olofsson with the SEM (Fig. 4) and we thank the staff at Stockholm Marine Science Center (Askö Laboratory) for excellent assistance in the field and in the laboratory.

Funding This study was funded by Oscar and Lili Lamm Foundation, The Swedish Research Council (VR No 2007-8365) and the Swedish Institute (scholarship for F. S. Steinhoff).

\section{Compliance with ethical standards}

Conflict of interest The authors declare that they have no conflict of interests.

Human and animal rights statement This article does not contain any studies with animals performed by any of the authors.

Open Access This article is distributed under the terms of the Creative Commons Attribution 4.0 International License (http://creativeco mmons.org/licenses/by/4.0/), which permits unrestricted use, distribution, and reproduction in any medium, provided you give appropriate credit to the original author(s) and the source, provide a link to the Creative Commons license, and indicate if changes were made.

\section{References}

Aberle N, Schulz KG, Stuhr A, Malzahn AM, Ludwig A, Riebesell U (2013) High tolerance of microzooplankton to ocean acidification in an Arctic coastal plankton community. Biogeosciences 10:1471-1481

Andersson AF, Riemann L, Bertilsson S (2010) Pyrosequencing reveals contrasting dynamics of taxa within Baltic Sea bacterioplankton. ISME J 4:171-181

Baho DL, Hannes P, Tranvik LJ (2012) Resistance and resilience of microbial communities - temporal and spatial insurance against perturbations. Environ Microbiol 14:2283-2292

Bermúdez R, Winder M, Stuhr A, Almén A-K, Engström-Öst J, Riebesell U (2016) Effect of ocean acidification on the structure and fatty acid composition of a natural plankton community in the Baltic Sea. Biogeosciences 13:6625-6635

Borges A, Frankignoulle M (1999) Daily and seasonal variations of the partial pressure of $\mathrm{CO}_{2}$ in surface seawater along Belgian and southern Dutch coastal areas. J Mar Syst 19:251-266

Brutemark A, Engström-Öst J, Vehmaa A, Gorokhova E (2015) Growth, toxicity and oxidative stress of a cultured cyanobacterium (Dolichospermum sp.) under different $\mathrm{CO}_{2} / \mathrm{pH}$ and temperature conditions. Phycol Res 63:56-63

Brzezinski MA (1985) The Si:C:N ratio of marine diatoms: interspecific variability and the effect of some environmental variables. J Phycol 21:347-357

Chierici M, Fransson A, Anderson LG (1999) Influence of m-creosol purple indicator additions on the $\mathrm{pH}$ of seawater samples: correction factors evaluated from a chemical speciation model. Mar Chem 65:281-290

Clayton TD, Byrne RH (1993) Spectrophotometric seawater pH measurements: total hydrogen ion concentration scale calibration of m-cresol purple and at-sea results. Deep Sea Res I. 40:2115-2129

Dickson AG, Millero FJ (1987) A comparison of the equilibrium constants for the dissociation of carbonic acid in seawater media. Deep-Sea Res I 34:1733-1743

Dickson AG, Sabine CL, Christian JR (2007) Guide to best practices for ocean $\mathrm{CO}_{2}$ measurements, PICES special publication 3. North Pacific Marine Science Organization, Sidney

Eichner M, Kranz SA, Rost B (2014a) Combined effects of $\mathrm{CO}_{2}$ levels and $\mathrm{N}$ sources on the diazotrophic cyanobacterium Trichodesmium. Physiol Plantarum 152:316-330

Eichner M, Rost B, Kranz SA (2014b) Diversity of ocean acidification effects on marine $\mathrm{N}_{2}$ fixers. J Exp Mar Biol Ecol 457:199-207

Endres S, Galgani L, Riebesell U, Schulz K-G, Engel A (2014) Stimulated bacterial growth under elevated $p \mathrm{CO}_{2}$ : results from an offshore mesocosm study. PLoS One. https://doi.org/10.1371/journ al.pone.0099228

Engel A, Borchard C, Piontek J, Schulz KG, Riebesell U, Bellerby R (2013) $\mathrm{CO}_{2}$ increases ${ }^{14} \mathrm{C}$ primary production in an Arctic plankton community. Biogeosciences 10:1291-1308

Engström-Öst J, Repka S, Mikkonen M (2011) Interactions between plankton and cyanobacterium Anabaena with focus on salinity, growth and toxin production. Harmful Algae 10:530-535

Fransson A, Chierici M, Anderson LG (2004) Diurnal variability in the oceanic carbon dioxide system and oxygen in the Southern Ocean surface water. Deep-Sea Res II 51:2827-2839

Fuhrman JA, Azam F (1982) Thymidine incorporation as a measure of heterotrophic bacterioplankton production in marine surface waters: evaluation and field results. Mar Biol 66:109-120

Gattuso JP, Gao K, Lee K, Rost B, Schulz KG (2010) Approaches and tools to manipulate the carbonate chemistry. In: Riebesell U, Fabry VJ, Hansson L, Gattuso JP (eds) Guide to best practices for ocean acidification research and data reporting. Publications Office of the European Union, Luxembourg, pp 41-52

Grasshoff K, Kremling K, Ehrhardt M (1999) Methods of seawater analysis, 3rd edn. Wiley, Weinheim

Grossart H, Allgaier M, Passow U, Riebesell U (2006) Testing the effect of $\mathrm{CO}_{2}$ concentration on the dynamics of marine heterotrophic bacterioplankton. Limnol Oceanogr 51:1-11

Guillard RRL (1975) Culture of phytoplankton for feeding marine invertebrates. In: Smith WL, Chanley MH (eds) Culture of marine invertebrate animals. Plenum, New York, pp 29-60

Gustafsson BG, Schenk F, Blenckner T, Eilola K, Meier HEM, MüllerKarulis B, Neumann T, Ruoho-Airola T, Savchuk OP, Zorita E (2012) Reconstructing the development of Baltic Sea eutrophication 1850-2006. Ambio 41:534-548

Hasselström L (2008) Tourism and recreation industries in the Baltic Sea area-How are they affected by the state of the marine environment? Swedish EPA, Rep. 5878, Stockholm, Sweden 
Havenhand JN (2012) How will ocean acidification affect Baltic Sea ecosystems? An assessment of plausible impacts on key functional groups. Ambio 41:637-644

HELCOM (2007) Climate change in the Baltic Sea area-HELCOM Thematic Assessment 2007. Balt Sea Environ Proc, No. 111

HELCOM (2013) Climate change in the Baltic Sea Area: HELCOM thematic assessment in 2013. Balt Sea Environ Proc, No. 137

HELCOM MONAS (2008) Guidelines concerning phytoplankton species composition, abundance and biomass. In: Manual for Marine Monitoring in the COMBINE Programme of HELCOM. http:// www.helcom.fi/helcom-at-work/publications/manuals-and-guide lines/. Accessed 1 Nov 2011

Hense I, Meier M, Sonntag S (2013) Projected climate change impact on Baltic Sea cyanobacteria. Clim Change 119:391-406

Herlemann DP, Labrenz M, Jürgens K, Bertilson S, Waniek JJ, Andersson A (2011) Transitions in bacterial communities along the $2000 \mathrm{~km}$ salinity gradient of the Baltic Sea. ISME J 5:1571-1579

Hogfors H, Motwani NH, Hajdu S, El-Shehawy R, Holmborn T, Vehmaa A, Engström-Öst J, Brutemark A, Gorokhova E (2014) Bloom-forming cyanobacteria support copepod reproduction and development in the Baltic Sea. PLoS One 9:112692

Hornick T, Bach LT, Crawfurd KJ, Spilling K, Achterberg EP, Woodhouse JN, Schulz KG, Brussaard CPD, Riebesell U, Grossart HP (2017) Ocean acidification impacts bacteria-phytoplankton coupling at low nutrient conditions. Biogeosciences 14:1-15

Hughes TP, Bellwood DR, Folke C, Steneck RS, Wilson J (2005) New paradigms for supporting the resilience of marine ecosystems. Trends Ecol Evol 20:380-386

IPCC (2013) Climate change 2013: the physical science basis. In: Stocker TF, Qin D, Plattner G-K, Tignor M, Allen SK, Boschung J, Nauels A, Xia Y, Bex V, Midgley PM (eds) Contribution of working group I to the fifth assessment report of the Intergovernmental Panel on Climate Change. Cambridge University Press, Cambridge and New York

Joint I, Doney SC, Karl DM (2011) Will ocean acidification affect marine microbes. ISME J 5:1-7

Kabel K, Moros M, Porsche C, Neumann T, Adolphi F, Andersen TJ, Siegel H, Gerth M, Leipe T, Jansen E, Damsté JSS (2012) Impact of climate change on the Baltic Sea ecosystem over the past 1000 years. Nat Clim Change 2:871-874

Kahru M, Elmgren R (2014) Multidecadal time series of satellitedetected accumulations of cyanobacteria in the Baltic Sea. Biogeosciences 11:3619-3633

Karlberg M, Wulff A (2013) Impact of temperature and species interaction on filamentous cyanobacteria may be more important than salinity and increased $p \mathrm{CO}_{2}$ levels. Mar Biol 160:2063-2072

Karlson AML, Duberg J, Motwani NH, Hogfors H, Klawonn I, Ploug H, Svedén JB, Garbaras A, Sundelin B, Hajdu S, Larsson U, Elmgren R, Gorokhova E (2015) Nitrogen fixation by cyanobacteria stimulates production in Baltic food webs. Ambio 44:413-426

Kim HC, Lee K (2009) Significant contribution of dissolved organic matter to seawater alkalinity. Geophys Res Lett. https://doi. org/10.1029/2009GL040271

Klawonn I, Nahar N, Walve J, Andersson B, Olofsson M, Svedén BJ, Littmann S, Whitehouse MJ, Ploug H (2016) Cell-specific nitrogen- and carbon-fixation of cyanobacteria in a temperate marine system (Baltic Sea). Environ Microb 18:4596-4609

Laamanen MJ, Forsström L, Sivonen K (2002) Diversity of Aphanizomenon flos-aquae (cyanobacterium) populations along a Baltic Sea salinity gradient. Appl Environ Microbiol 68:5296-5303

Langenheder S, Kisand V, Wikner J, Tranvik LJ (2003) Salinity as a structuring factor for the composition and performance of bacterioplankton degrading riverine DOC. FEMS Microbiol Ecol 45:189-202
Lee S, Fuhrman JA (1987) Relationship between biovolume and biomass of naturally derived marine bacterioplankton. Appl Environ Microbiol 536:1298-1303

Lehtimäki J, Moisander P, Sivonen K, Kononen K (1997) Growth, nitrogen fixation and nodularin production by two Baltic Sea cyanobacteria. Appl Env Microb 63:1647-1656

Lindh MV, Riemann L, Baltar F, Romero-Oliva C, Salomon PS, Granéli E, Pinhassi J (2013) Consequences of increased temperature and acidification on bacterioplankton community composition during a mesocosm spring bloom in the Baltic Sea. Environ Microbiol Rep 5:252-262

Lischka S, Bach LT, Schulz K-G, Riebesell U (2017) Ciliate and mesozooplankton community response to increasing $\mathrm{CO}_{2}$ levels in the Baltic Sea: insights from a large-scale mesocosm experiment. Biogeosciences 14:447-466

Marie D, Partensky F, Jacquet S, Vaulot D (1997) Enumeration and cell cycle analysis of natural populations of marine picoplankton by flow cytometry using the nucleic acid stain SYBR Green I. Appl Environ Microbiol 63:186-193

Mattsdotter-Björk M, Fransson A, Torstensson A, Chierici M (2014) Ocean Acidification in western Antarctic surface waters: drivers and interannual variability. Biogeosciences 11:57-73

Mazur-Marzec H, Zeglinska L, Plinski M (2005) The effect of salinity on the growth, toxin production, and morphology of Nodularia spumigena isolated from the Gulf of Gdansk, southern Baltic Sea. J Appl Phycol 17:171-179

Meehl GA, Stocker TF, Collins WD et al (2007) Global climate projections. In: Solomon S, Qin D, Manning M et al (eds) Climate change 2007: the physical science basis. Contribution of working group I to the fourth assessment report of the intergovernmental panel on climate change. Cambridge University Press, Cambridge and New York

Mehrbach C, Culberson CH, Hawley JE, Pytkowicz RM (1973) Measurement of the apparent dissociation constants of carbonic acid in seawater at atmospheric pressure. Limnol Oceanogr 18:897-907

Mohlin M, Wulff A (2009) Interaction effects of ambient UV radiation and nutrient limitation on the toxic cyanobacterium Nodularia spumigena. Microb Ecol 57:675-686

Mohlin M, Roleda MY, Pattanaik B, Tenne S-J, Wulff A (2012) Interspecific resource competition-combined effects of radiation and nutrient limitation on two diazotrophic filamentous cyanobacteria. Microb Ecol 63:736-750

Möllmann C, Diekmann R, Müller-Karulis B, Kornilovs G, Plikshs M, Axe P (2009) Reorganization of a large marine ecosystem due to atmospheric and anthropogenic pressure: a discontinuous regime shift in the Central Baltic Sea. Global Change Biol 15:1377-1393

Nydahl A, Panigrahi S, Wikner J (2013) Increased microbial activity in a warmer and wetter climate enhances the risk of coastal hypoxia. FEMS Microbiol Ecol 85:338-347

Oksanen J, Blanchet FG, Friendly M, Kindt R, Legendre P, McGlinn D, Minchin PR, O'Hara RB, Simpson GL, Solymos P, Stevens MHM, Szoecs E, Wagner H (2017) vegan: community ecology package. R package version 2.4-4. https://CRAN.R-project.org/ package=vegan. Accessed 1 Nov 2017

Olofsson M, Egardt J, Singh A, Ploug H (2016) Inorganic phosphorus enrichments in Baltic Sea water have large effects on growth, carbon- and $\mathrm{N}_{2}$-fixation by Nodularia spumigena. Aquat Microb Ecol 77:111-123

Paerl HW, Huisman J (2008) Blooms like it hot. Science 320:57-58

Pattanaik B, Wulff A, Roleda MY, Garde K, Mohlin M (2010) Production of the cyanotoxin nodularin-a multifactorial approach. Harmful Algae 10:30-38

Paul AJ, Achterberg EP, Bach LT, Boxhammer T, Czerny J, Haunost M, Schulz K-G, Stuhr A, Riebesell U (2016) No observed effect of ocean acidification on nitrogen biogeochemistry in a summer Baltic Sea plankton community. Biogeosciences 13:3901-3913 
Pierrot D, Lewis E, Wallace DWR (2006) MS Excel Program developed for $\mathrm{CO}_{2}$ system calculations, ORNL/CDIAC-105. Carbon Dioxide Information Analysis Center, Oak Ridge National Laboratory, U.S. Department of Energy, Oak Ridge

Ploug H (2008) Cyanobacterial aggregates formed by Aphanizomenon sp. and Nodularia spumigena in the Baltic Sea: small-scale fluxes, pH and oxygen microenvironments. Limnol Oceanogr 53:914-921

Ploug H, Musat N, Adam B, Moraru CM, Bergman B, Lavik G, Vagner T, Bergman B, Kuypers MMM (2010) Small-scale carbon and nitrogen fluxes associated with Aphanizomenon sp. in the Baltic Sea. ISME J 4:1215-1223

Ploug H, Adam B, Musat N, Kalvelage T, Lavik G, Wolf-Gladrow D, Kuypers MMM (2011) Carbon, nitrogen and $\mathrm{O}_{2}$ fluxes associated with the cyanobacterium Nodularia spumigena in the Baltic Sea. ISME J 5:1549-1558

R Core Team (2016) R: A language and environment for statistical computing. R Foundation for Statistical Computing, Vienna, Austria. https://www.R-project.org/. Accessed 1 Nov 2017

Raven J, Caldeira K, Elderfield H, Hoegh-Guldberg O, Liess P, Riebesell U, Shephard J, Turley C, Watson A (2005) Ocean acidification due to increasing atmospheric carbon dioxide. Policy document $12 / 05$ by The Royal Society, London

Reinfelder JR (2011) Carbon concentrating mechanisms in eukaryotic marine phytoplankton. Annu Rev Mar Sci 3:291-315

Riebesell U, Gattuso J-P (2015) Lessons learned from ocean acidification research. Nat Clim Change 5:12-14

Riemann L, Leitet C, Pommier T, Simu K, Holmfeldt K, Larsson U, Hagström $\AA$ (2008) The native bacterioplankton community in the central Baltic Sea is influenced by freshwater bacterial species. Appl Environ Microbiol 74:503-515

Schulz KG, Riebesell U (2013) Diurnal changes in seawater carbonate chemistry speciation at increasing atmospheric carbon dioxide. Mar Biol 160:1889-1899

Shade A, Peter H, Allison SD, Baho DL, Berga M, Bürgmann H, Huber DH, Langenheder S, Lennon JT, Martiny JB, Matulich KL, Schmidt TM, Handelsman J (2012) Fundamentals of microbial community resistance and resilience. Front Microbiol 3:1-19

Sivonen K, Halinen K, Sihvonen LM, Koskenniemi K, Sinkko H, Rantasärkkä K, Moisander PH, Lyra C (2007) Bacterial diversity and function in the Baltic Sea with emphasis on cyanobacteria. Ambio 36:180-185

Smith DC, Azam F (1992) A simple, economical method for measuring bacterial protein synthesis rates in seawater using ${ }^{3} \mathrm{H}$-leucine. Mar Microb Food Webs 6:102-114

Solorzano L, Sharp JH (1980) Determination of total dissolved phosphorus and particulate phosphorus in natural waters. Limnol Oceanogr 25:754-757

Torstensson A, Hedblom M, Andersson J, Andersson MX, Wulff A (2013) Synergism between elevated $p \mathrm{CO}_{2}$ and temperature on the Antarctic sea ice diatom Nitzschia lecointei. Biogeosciences 10:6637-6669

Torstensson A, Hedblom M, Björk MM, Chierici M, Wulff A (2015) Long-term acclimation to elevated $p \mathrm{CO}_{2}$ alters carbon metabolism and reduces growth in the Antarctic diatom Nitzschia lecointei. $\mathrm{P}$ Roy Soc B-Biol Sci 282:20151513

Underwood AJ (1997) Experiments in ecology: their logical design and interpretation using analysis of variance. Cambridge University Press, Cambridge

Vahtera E, Conley DJ, Gustafsson BG, Kuosa H, Pitkänen H, Savchuk OP, Tamminen T, Viitasalo M, Voss M, Wasmund N, Wulff F (2007a) Internal ecosystem feedbacks enhance nitrogen-fixing cyanobacteria blooms and complicate management in the Baltic Sea. Ambio 36:186-194

Vahtera E, Laamanen M, Rintala JM (2007b) Use of different phosphorus sources by the bloom-forming cyanobacteria Aphanizomenon flos-aquae and Nodularia spumigena. Aquat Microb Ecol 46:225-237

Wannicke N, Endres S, Engel A, Grossart HP, Nausch M, Unger J, Voss M (2012) Response of Nodularia spumigena to $p \mathrm{CO}_{2}$ part 1: growth, production and nitrogen cycling. Biogeosciences 9:2973-2988

Wasmund N (1997) Occurrence of cyanobacterial blooms in the Baltic Sea in relation to environmental conditions. Int Rev Ges Hydrobiol 82:169-184

Wright S, Jeffrey S (1997) High-resolution HPLC system for chlorophylls and carotenoids of marine phytoplankton. In: Jeffrey S, Mantoura R, Wright S (eds) Phytoplankton pigments in oceanography. UNESCO, Paris, pp 327-341

\section{Affiliations}

\section{Angela Wulff' ${ }^{1}$ - Maria Karlberg ${ }^{1} \cdot$ Malin Olofsson $^{2} \cdot$ Anders Torstensson $^{1,5} \cdot$ Lasse Riemann $^{3}$. Franciska S. Steinhoff ${ }^{1} \cdot$ Malin Mohlin $^{4} \cdot$ Nina Ekstrand ${ }^{2} \cdot$ Melissa Chierici $^{2,6}$}

1 Department of Biological and Environmental Sciences, University of Gothenburg, Box 461, 40530 Göteborg, Sweden

2 Department of Marine Sciences, University of Gothenburg, Box 461, 40530 Göteborg, Sweden

3 Department of Biology, Marine Biological Section, University of Copenhagen, Strandpromenaden 5, 3000 Helsingør, Denmark
4 Swedish Meteorological and Hydrological Institute, Sven Källfelts gata 15, 42671 Västra Frölunda, Sweden

5 Present Address: School of Oceanography, University of Washington, Box 357940, Seattle, WA 98195, USA

6 Present Address: Institute of Marine Research, Sykehusveien 23, Troms $\varnothing$, Norway 